\section{The role of radio in rescuing the survivors of the airship Italia}

Harvey M. Solomon ${ }^{1}$ \& Philip Cala-Lazar ${ }^{2}$

${ }^{1}$ HCR 74, Box 24807, El Prado, NM 87529, USA

26901 Lyons St., Morton Grove, IL 60053, USA

During WWI, rapid technical advances led to the development of relatively small and efficient short wave transmitters and receivers. By the mid-1920s, explorers of the polar regions were using such equipment to communicate with their home bases, and for direction finding. This was prior to the widespread use of radio for voice transmission, and hence all operators were skilled in the use of the International Morse code.

The airships Norge and Italia used radios for communication during their Arctic voyages (Fig. 1). Considerable information has already been published about the equipment on board the Norge (Amundsen \& Ellsworth 1927: 283-315), but relatively little is readily available concerning that on the Italia (Nobile 1961; International Guglielmo Marconi Committeee n.d. a), despite the major role that radio played in the rescue of the crash survivors.

Electronic storage and retrieval of previously difficultto-obtain information has greatly facilitated access to detailed information about the Italia's radios (International Guglielmo Marconi Committee n.d. b, c). This letter aims to make this information accessible in English.

The Italia's radio complement included a Marconi RA8 transmitter and a Marconi RA6 receiver, part of a series of radios developed for military aircraft. The RA8 transmitter utilized two Osram-Marconi T250 vacuum tubes rated at $300 \mathrm{~W}$ over a frequency range of $600-900 \mathrm{~m}$ waveband. (The transmitter is on display at the Technical Naval Museum of La Spezia [Museo Tecnico Navale della Spezia]), and a photograph of it can be seen on the museum's website.) The loop antenna used at these wavelengths comprised $100 \mathrm{~m}$ of bronze wire wound in a drum-shaped configuration. Storage cells provided power to the radio gear, and were charged by a Marelli dynamo driven by a propeller that could be deployed into the airflow.

For short wave reception, an English Burndept MK IV, employing three Mullard S 525 vacuum tubes and covering $12-100 \mathrm{~m}$ via interchangeable coils, was used. The

\section{Correspondence}

H. M. Solomon, HCR 74, Box 24807, El Prado, NM 87529, USA. E-mail: H4020@aol.com

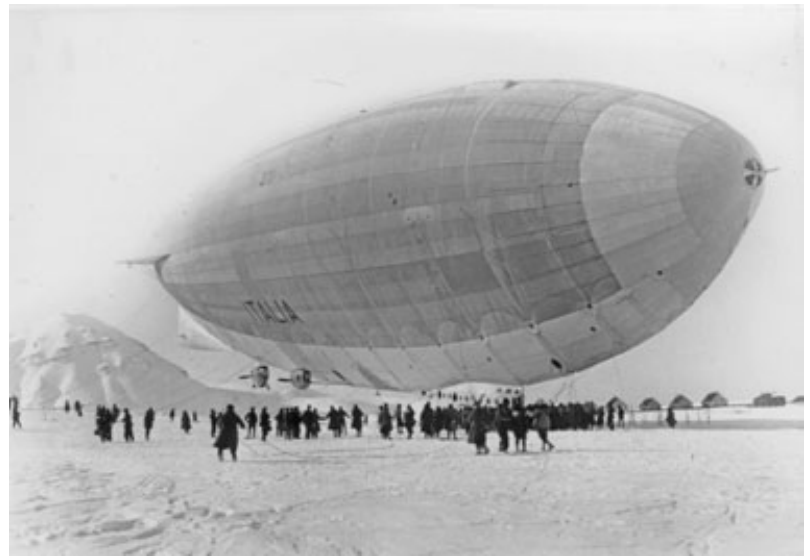

Fig. 1. The airship Italia. Under the command of Umberto Nobile, the Italia departed Ny-Ålesund, Spitsbergen, on 23 May 1928 and dropped an Italian flag and wooden cross on the North Pole on 24 May. (Courtesy of Norwegian Polar Institute Photo Library.)

short wave transmitter employed a Philips TB 0410 triode and was of a Hartley-type oscillator design. It generated $5 \mathrm{~W}$ output over a range of between 30 and $50 \mathrm{~m}$. The entire miniaturized unit fitted into a wooden chest and weighed about $12 \mathrm{~kg}$. An off-centre fed antenna was installed, with the three-quarter-wavelength leg running towards the Italia's bow and the quarter-wavelength leg running towards the airship's stern. The Italia was also outfitted with a Marconi DFM 2 direction finder of the Bellini-Tosi design.

Following the crash of the airship on 25 May 1928, petty officer second class Giuseppe Biagi (International Guglielmo Marconi Committee n.d. d), the only radio operator on the expedition, recovered the emergency transmitter and receiver. An aluminium tube salvaged from the wrecked control cabin was erected as a quarterwave antenna, and a counterpoise was stretched on the ice (Fig. 2). The recovered batteries were intact and would last for $60 \mathrm{~h}$. Biagi transmitted a distress call on $33 \mathrm{~m}$ every 55 minutes in a pattern prearranged with their support ship the Città di Milano. The vessel never received these signals. Twelve days later, while listening to San Paolo (IDO) in Rome on $32 \mathrm{~m}$, Biagi learned that Nicolai Schmidt, a Russian amateur radio operator located near Archangel, had received his distress call and had alerted the Soviet authorities, who passed the information to the Italian government. The rest of the story of the rescue of the survivors is well known (Fig. 3). 


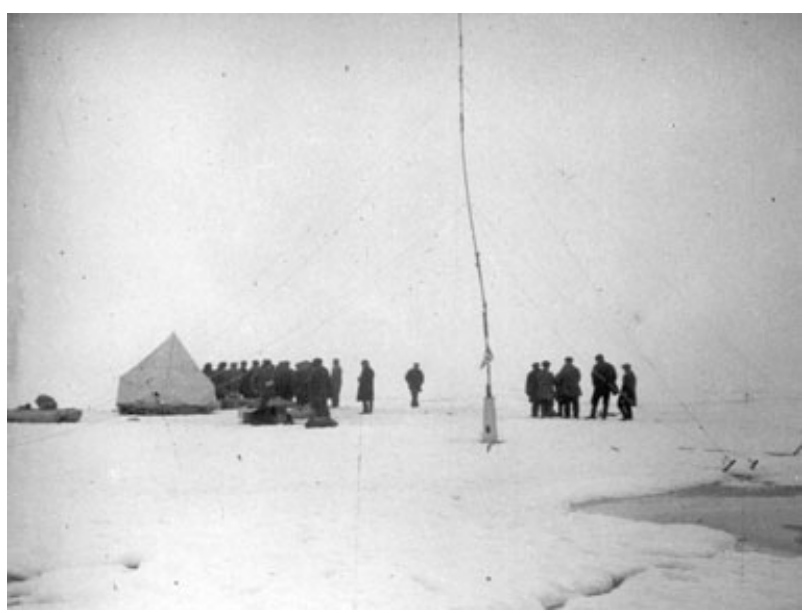

Fig. 2. Stranded on the ice to the north-east of Svalbard, the survivors of the crash erected a makeshift radio antenna. (Photo by A. Hoel; courtesy of Norwegian Polar Institute Photo Library.) Photographs of the radio equipment can be viewed online at www.radiomarconi.com/marconi/ biagi1.jpg and www.radiomarconi.com/marconi/la_biagina.jpg.

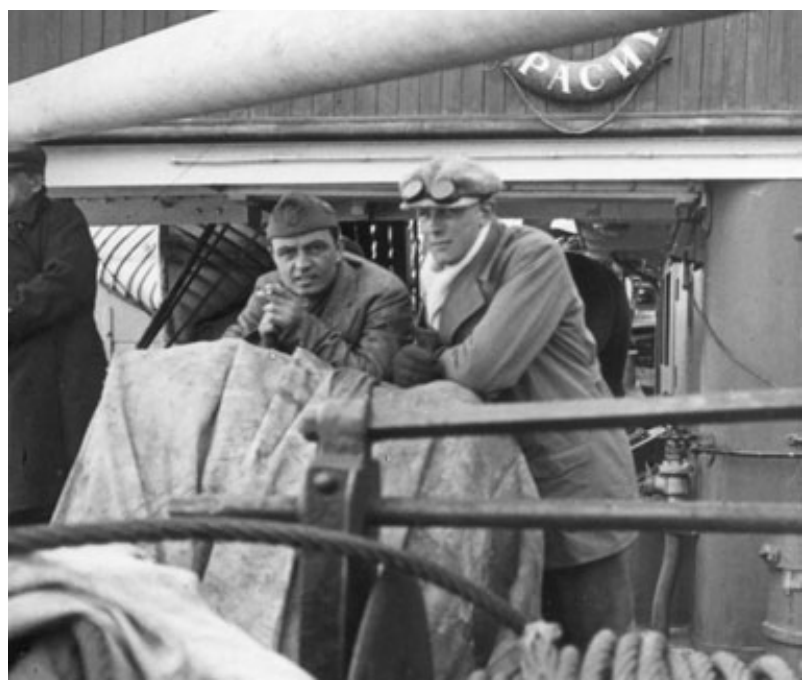

Fig. 3. Giuseppe Biagi (left) on board the Krassin shortly after the rescue. (Photo by A. Hoel; courtesy of Norwegian Polar Institute Photo Library.)

\section{References}

Amundsen R. \& Ellsworth L. 1927. First crossing of the polar sea. New York: G.H. Doran Company.

Nobile U. 1961 My polar flights. New York: G.P. Putnam's Sons.

International Guglielmo Marconi Committee (Comitato Guglielmo Marconi International) n.d. a. La tenda rossa: 70 anniversario della spedizione del dirigible Italia.

(The red tent: 70th anniversary of the expedition of the airship Italia.) Accessed on the internet at http:// www.radiomarconi.com/marconi/nobilel/index.html on 21 January 2008.

International Guglielmo Marconi Committee (Comitato Guglielmo Marconi International) n.d. b. Guiseppe Biagi-la tenda rossa. (Guiseppe Biagi-the red tent.) Accessed on the internet at http://www.radiomarconi.com/ marconi/biagi.html on 21 January 2008.

International Guglielmo Marconi Committee (Comitato Guglielmo Marconi International) n.d. c. Guiseppe Biagi, O.M. Emerito dell'A.R.I. (Guiseppe Biagi, member emeritus of the A.R.I. [Association Italian Amateur Radio Operators]). Accessed on the internet at http://www.radiomarconi.com/marconi/nobile/ giuseppe_biagi.html on 21 January 2008.

International Guglielmo Marconi Committee (Comitato Guiglielmo Marconi International) n.d. d. L'anniversario della spedizione di Biagi. (The anniversary of the expedition of Biagi.) Accessed on the internet at www.radiomarconi.com/marconi/biagil.html on 21 January 2008. 